\title{
УДОСКОНАЛЕННЯ МЕТОДИЧНИХ ПІДХОДІВ ДО ЕКОНОМІЧНОГО ОБГРУНТУВАННЯ ІНВЕСТИЦІЙ У РОЗВИТОК ПОРТОВОЇ ІНФРАСТРУКТУРИ
}

\author{
Жихарсва В.В., д.е.н., професор, \\ Ігнатенко Я.В., бакалавр з економіки, студентка магістратури,
} Діброва І.В., бакалавр з економіки, студентка магістратури (ОНМУ)

У статті удосконалені методичні підходи до економічного обтрунтування інвестииій у розвиток портової інфраструктури, які враховують галузеву специфіку стивідорних підприємств у морських портах, а саме: уточнений зміст етапів обтрунтування проектів будівниџтва вантажних причалів, запропонована класифікація ризиків, пов'язаних із проектами будівництва причалів, шляхом уточнення факторів галузевих, політичних, фінансових, правових і організачійно-управлінських ризиків.

Ключові слова: морські порти, інвестиції, інфраструктура, економічне обтрунтування, ризики.

\section{СОВЕРШЕНСТВОВАНИЕ МЕТОДИЧЕСКИХ ПОДХОДОВ К ЭКОНОМИЧЕСКОМУ ОБОСНОВАНИЮ ИНВЕСТИЦИЙ В РАЗВИТИЕ ПОРТОВОЙ ИНФРАСТРУКТУРЫ}

\begin{abstract}
Жихарева В.В., д.э.н., профессор,
Игнатенко Я.В., бакалавр по экономике, студентка магистратуры, Диброва И.В., бакалавр по экономике, студентка магистратуры (ОНМУ)

В статье усовершенствованы методические подходы $к$ экономическому обоснованию инвестиций в развитие портовой инфраструктуры, которые учитывают отраслевую специфику стивидорных предприятий в морских портах, а именно: уточнено содержание этапов обоснования проектов строительства грузовых причалов, предложена классификачия рисков, связанных с проектами строительства причалов, путем уточнения факторов отраслевых, политических, финансовых, правовых и организаџионно-управленческих рисков.
\end{abstract}

Ключевые слова: морские порты, инвестиции, инфраструктура, экономическое обоснование, риски.

\section{IMPROVING OF METHODICAL APPROACH TO ECONOMIC EVALUATION OF INVESTMENTS FOR DEVELOPMENT OF PORT INFRASTRUCTURE}

Zhykharieva V.V., D.Sc. in Economics, Professor, Ignatenko Y.V., bachelor of economics, student of MA course, Dibrova I.V., bachelor of economics, student of MA course (ONMU)

Taking into account changes in cargo traffic and growth of vessels' size, sea ports need to increase its capacity. As the investment projects for building of cargo piers in sea ports are very expensive it is necessary to improve methodical basis of investment efficiency

(C) Жихарєва В.В., Ігнатенко Я.В., Вісник економіки транспорту і промисловості № 67, 2019 Діброва I.В. 
evaluation. In the article the methodical approach of economic evaluation of investments for port infrastructure development, taking into account specifics of port industry, are improved: the content of the stages of evaluation of investment projects for building of cargo piers in sea ports are refined.

The classification of risks connected with projects for building of cargo is elaborated. The risks connected with investment projects in sea ports and stevedoring activity may be classified on such groups: industrial, political, financial, legal, organizational and managerial risks and force majeure risks. The most important industrial risks influencing on port enterprises are: competition between ports in certain region of stevedoring activity; tonnage restrictions for vessels; changes in tariff politics in transport industry; development of cargo handling capacities in ports-competitors; changes on the freight market etc. Political risks is connected with possible losses of enterprise as a result of unstable economical and political situation, change of top management on the level of enterprise or industry by political reasons, imperfective transport and port state politics. Financial risks include risks connected with possibility of interest rates change, exchange rates volatility, inflationary risk, credit risk and liquidity risk. Legal risks include: risks connected with changes in currency control; risks connected with changes in tax low; criminal risks; risks connected with general legal regulation of port sphere etc. Organizational and managerial risks include risk connected with investment planning, operational risk, personnel risk. It is proposed such main factors of project risk influencing on economic effect as operational earnings, operational costs and capital costs on building and purchase of loading equipments.

Keywords: sea ports, investments, infrastructure, economic evaluation, risks.

Постановка проблеми. Морські порти є складовою частиною транспортної та виробничої інфраструктури держави. Від ефективності їх функціонування, рівня технологічного та технічного оснащення, відповідності системи управління та розвитку інфраструктури сучасним міжнародним вимогам залежить конкурентоспроможність вітчизняного транспортного комплексу на світовому ринку. До проблем функціонування та розвитку портової галузі України відносяться: зниження рівня прибутковості морських портів у зв'язку із значним зносом основних засобів; повільне оновлення основних засобів, невідповідність їх технічного рівня вимогам щодо надання послуг iз здійснення операцій 3 вантажами; проблеми, пов'язані 3 функціонуванням механізму залучення приватних інвестицій для розвитку морських портів та захистом прав інвесторів; зменшення обсягу транзитних вантажопотоків у зв'язку 3 недостатньо розвинутою інфраструктурою морських портів (зокрема, недостатньою глибиною та довжиною причалів) та ін.

Ключові напрями розвитку морської галузі України визначені у Національній транспортної стратегії України до 2030 року [1], де сформульовані основні стратегічні напрямки розвитку портової галузі у інвестиційній сфері: забезпечення комплексного розвитку та підвищення конкурентоспроможності портової галузі; забезпечення належного утримання, ефективного управління та використання стратегічних об’єктів портової інфраструктури; залучення на довгостроковий період приватних інвестицій для розвитку об'єктів портової інфраструктури. Питання економічного обгрунтування інвестицій $\epsilon$ актуальним, оскільки морські порти мають потребу у збільшенні пропускної здатності у зв'язку зі зміною вантажопотоків i зростанням розмірів морських суден.

Аналіз останніх досліджень та публікацій. Проблеми розвитку портової галузі розглядалися у роботах зарубіжних i вітчизняних науковців. У статті E.L. 
Musso, A.S. Bergantino, F. Porcelli [2] розглянуті економічні засади управління розвитком портової діяльності. У публікаціях О.М. Кібік [3], М.Т. Примачова, Н.Н. Примачової [4] досліджені напрями реформування портів, підвищення ефективності функціонування і регулювання їх діяльності в Україні.

Питання техніко-економічного обгрунтування проектів розвитку підприємств транспорту розглянуті у роботах В.І. Краєва [5], Ю.Ф. Кулаєва [6]. $\mathrm{y}$ роботі B.I. Краєва розглядаються питання обгрунтування інвестицій у флот, у роботі Ю.Ф. Кулаєва - загальні питання інвестиційного проектування на транспорті.

Питання оцінки доходності
інвестицій розглянуті у роботах зарубіжних і вітчизняних авторів [7, 8, 9, 10]. Реалізація інвестиційного проекту повинна забезпечувати інвестору очікувану доходність, порівнянну з рівнем ризику. Критерій прийняття інвестиційних рішень із урахуванням ступеня ризику формулюється таким чином: інвестиційний проект уважається ефективним, якщо його прибутковість і ризик збалансовані в прийнятній для учасника проекту пропорції. Ризики, пов'язані 3 підприємницької діяльністю, вивчали такі автори як В.М. Гранатуров [11, 12], Л.І. Донець [13].

Виділення невирішених частин загальної проблеми. Аналіз публікацій по розглянутій проблемі показав, що методичні підходи до обгрунтування інвестиційних проектів, пов'язаних 3 розвитком портової інфраструктури, які враховують специфіку портової діяльності, не достатньо розвинути, а у практиці діяльності портових підприємств використовуються підходи до інвестиційного проектування, які часто не передбачають комплексну оцінку ризиків або виконується лише якісний аналіз окремих видів ризиків.

Метою статті $\epsilon$ удосконалення методичних засад економічного обгрунтування інвестиційних проектів, пов'язаних 3 розвитком портової інфраструктури, які враховують галузеву специфіку діяльності портових підприємств.

Виклад основного матеріалу дослідження. Проект об'єкта капітального будівництва у морському порту - це комплекс необхідних для досягнення певних цілей законних дій у сукупності із проектними матеріалами, що містять опис і обгрунтування об'єкта проектування та інших дій (робіт, послуг, управлінських операцій i рішень). Склад проектних матеріалів включає проектну документацію, у тому складі: технікоекономічне обгрунтування (ТЕО) проекту; норми, правила, положення та ін.; проект будівництва у формі техніко-економічних документів (креслень, технічних i кошторисних розрахунків, макетів, планів розміщення та комплектації, пояснювальних записок та ін.), що характеризують систему цілей, фізичних об'єктів i технологічних процесів для їхньої реалізації, необхідні матеріальні, трудові та фінансові ресурси; обгрунтування інвестицій у будівництво об'єкта; бізнес-план за певною формою; додаткові матеріали, що розроблюються при експертизі проектів, їх підготовці та реалізації (у формі пропозицій, ескізних проектів, схем і т. ін.).

Особливу роль у системі проектування об'єктів капітального будівництва виконує техніко-економічне обгрунтування. TEO - це комплекс розрахунково-аналітичних документів, що містять як вихідні дані, так i основні технічні та організаційні рішення, розрахунково-кошторисні та інші показники, які дозволяють розглядати доцільність i ефективність проекту капітального будівництва. В ході ТЕО необхідно оцінити рентабельність бізнесу та доцільність його розвитку, а також указати 3 мінімальними погрішностями строки окупності або реалізації фінансових завдань. Розробляється ТЕО 
підприємствами або проектними організаціями. Зміст техніко-економічного обгрунтування приймаються по взаємному узгодженню замовника та проектної організації й відображаються в договорі. На практиці не існує єдиного підходу до
TEO і його універсальної моделі, яка б охоплювала виробничі проекти будь-якого типу та розміру.

Техніко-економічне обгрунтування на транспорті має включати укрупнені етапи, наведені на рис. 1.

\section{Укрупнені етапи техніко-економічного обгрунтування на транспорті}

Етап 1. Визначення перспективного обсягу та характеру транспортної роботи майбутнього спорудження, напрямків і обсягу перевезень, вантажообігу. При цьому необхідно характеризувати обсяг роботи найбільше повно (по номенклатурі, видам перевезень, сезонності, розмірам партій вантажів і т. ін.).

Етап 2. Встановлення основних умов експлуатації об'єкта проекту, які впливають на вибір його техніко-експлуатаційних характеристик.

Етап 3. Розробка основних техніко-експлуатаційних характеристик об'єкта проекту або їх можливих варіантів.

Етап 4. Розрахунок показників економічної ефективності проекту, включаючи показники доходності та ризику, які повинні надати оцінку абсолютної ефективності проекту, або розрахунки по кожному 3 варіантів, які повинні надати оцінку порівняльної ефективності.

Етап 5. Вибір і обгрунтування оптимального варіанта на підставі зіставлення та аналізу показників ефективності проекту. Прийняття рішення щодо доцільності реалізації проекту та шляхів мінімізації ризиків.

\section{Рис. 1. Укрупнені етапи техніко-економічного обтрунтування на транспорті [розроблено авторами]}

Дослідження підходів до технікоекономічного обгрунтування інвестицій на транспорті дозволило удосконалити методичні підходи до економічного обгрунтування інвестиційного проекту будівництва вантажного причалу $\mathrm{y}$ морському порту. 3 цією метою були розроблені основні етапи економічного обгрунтування інвестиційних проектів, пов'язаних 3 будівництвом вантажних причалів у морських портах (рис. 2).

До основних груп факторів ризику, пов'язаного із проектами будівництва причалів, пропонується віднести галузеві, політичні, фінансові, правові, організаційно-управлінські ризики й ризики форс-мажор. 
Основні етапи економічного обгрунтування інвестиційних проектів, пов'язаних з будівництвом вантажних причалів у морських портах

Етап 1. Аналіз основних виробничих і фінансових показників підприємства для визначення обсягів вантажообороту, суднообороту i фінансових можливостей, включаючи аналіз змін у структурі вантажопотоків з урахуванням ситуації на ринку стивідорних послуг і аналіз переробки вантажів по причалах порту.

Етап 2. Обгрунтування доцільності збільшення пропускної спроможності порту 3 урахуванням структури вантажообігу і оборотності причалів.

Етап 3. Визначення етапів реалізації проекту, проектних показників з урахуванням потреби обробки суден певного розміру. Виявлення потреби в перевантажувальному обладнанні з урахуванням рівня інтенсивності навантажувально-розвантажувальних робіт. Розрахунок строку виконання будівельних робіт по етапах проекту.

Етап 4. Визначення проектної вартості етапів проекту і загальної величини капітальних інвестицій у будівництво.

Етап 5. Визначення на основі аналізу фінансових показників джерел фінансування проекту, доцільність залучення позикового фінансування або інвестора.

Етап 6. Аналіз інвестиційного проекту для виявлення вузьких місць роботи порту і погроз зовнішнього і внутрішнього середовища. Рекомендується розглянути такі внутрішні фактори проекту як ступінь його капіталомісткості, підходи до вибору підрядчиків, можливе збільшення потреби у перевантажувальній техніці та ін.

Етап 7. Оцінка прибутковості інвестиційного проекту на основі розрахунку прогнозних експлуатаційних і чистих грошових потоків, пов'язаних з реалізацією інвестиційного проекту з урахуванням капітальних інвестицій.

Етап 8. Розрахунок показників доходності інвестицій і періоду окупності. Період окупності інвестицій для великих проектів може становити більше десяти років, що $\epsilon$ прийнятним для капіталомістких проектів.

Етап 9. Якісна та кількісна оцінка ризиків проекту.

Етап 10. Вибір оптимального варіанта на підставі показників доходності та ризику. Рішення щодо доцільності реалізації проекту

Етап 11. Розробка шляхів мінімізації ризиків, пов'язаних з проектом.

Рис. 2. Основні етапи економічного обтрунтування інвестиційних проектів, пов'язаних з будівництвом вантажних причалів у морських портах [розроблено авторами] 
Найбільш значимими галузевими ризиками, які впливають на діяльність портових підприємств, є: конкуренція між морськими портами в регіоні, де здійснюються стивідорні операції; перебої або затримки в роботі українських залізних і автомобільних доріг; тоннажні обмеження проходу вантажних суден через протоки Босфор, Дарданелли, Мармурового моря та ін.; зміна тарифної політики у транспортної галузі, особливо зміна залізничних тарифів; розвиток нових перевантажувальних потужностей у портах-конкурентах; зміни на світовому фрахтовому ринку, пов'язані зі зростанням ставок на перевезення вантажів; збільшення вартості енергетичних ресурсів; можливість підвищення ставки орендних платежів по гідротехнічних спорудженнях і земельних ділянках; можливе зниження обсягу перевалок або зменшення клієнтської бази.

Країнові (політичні) ризики пов'язані 3 негативними змінами в портовому секторі внаслідок нестабільної політичної та економічної ситуації, зміною керівництва на рівні підприємства i галузі 3 політичних причин, недосконалою транспортною та портовою політикою держави.

Фінансові ризики включають наступні види ризиків. Фінансові ризики, які пов'язані з ризиком зміни процентних ставок, виникають при наявності в кредитному портфелі компанії кредитів із плаваючою процентною ставкою LIBOR, зміна якої прямо впливає на фінансовий результат компанії. Відсоткова ставка чутлива до зміни цілого ряду факторів, що перебувають поза контролем підприємства, у тому числі таких, як внутрішні та міжнародні економічні умови, політика центральних банків і т.д. Підвищення відсоткової ставки призведе до збільшення видатків по зовнішньому фінансуванню.

Фінансові ризики, пов'язані зі змінами валютних курсів. Основний валютний ризик для стивідорного підприємства пов'язаний 3 коливаннями обмінних курсів гривні до долару США. У зв'язку з тим, що тарифи за перевалку визначені в доларах США, підвищення курсу гривні відносно долару США може спричинити зниження виторгу, прибутку та рентабельності. Зміна курсу іноземних валют відносно гривні може привести до зміни статті балансу, що відображає заборгованість по кредитах і позикам, виражених в іноземній валюті. Зниження курсу іноземної валюти відносно гривні веде до збільшення позитивних курсових різниць від переоцінки кредитів i спричиняє збільшення зобов'язань по сплаті податку на прибуток. Відповідно зростання курсу іноземної валюти відносно гривні веде до зменшення позитивних курсових різниць від переоцінки кредитів і спричиняє зниження зобов'язань по сплаті податку на прибуток. Інфляційні ризики, пов'язані 3 інфляційними процесами, у результаті яких відбувається подорожчання матеріалів, палива, можуть позначитися на збільшенні валюти балансу, а також вплинути на чистий прибуток компанії у зв'язку з тим, що можливості стивідорного підприємства по встановленню тарифів на навантажувально-розвантажувальні роботи обмежені державним регулюванням, у той час як витрати, які, в основному, виражені в гривнях, змінюються відповідно до темпів інфляції. Зміна індексу споживчих цін впливає на рівень рентабельності компанії, i, як наслідок, на фінансовий стан і можливість виконання зобов'язань, однак цей вплив не $€$ чинником прямої залежності.

Кредитний ризик укладається в тім, що клієнт може не виконати свої зобов'язання перед стивідорним підприємством у строк, що спричинить виникнення фінансових збитків. Перед початком співробітництва 3 новим клієнтом варто виконувати оцінку його кредитоспроможності. 
Ризик ліквідності укладається в тому, що підприємство не зможе виконати свої зобов'язання при настанні строку їх погашення.

Правові ризики, пов'язані 3 правовою системою, включають наступні.

Ризики, пов'язані зі зміною валютного регулювання. Зміна валютного регулювання може негативно відбитися на виконанні зобов'язань по договорах, раніше ув'язненим 3 українськими й іноземними контрагентами, що передбачає необхідність здійснення платежів по них в іноземній валюті, і зажадати висновки додаткових угод до відповідних договорів (контрактам). У випадку залучення фінансування у валюті, відмінної від валюти України, підприємство повинно прагнути побудувати свою діяльність таким чином, щоб платежі по запозиченнях здійснювалися у валюті, що відповідає валюті своїх зобов'язань. У зв'язку із цим стивідорне підприємство в меншому ступені піддається ризикам зміни валютного регулювання й валютного контролю.

Ризики, пов'язані зі зміною податкового законодавства. Нормативні правові акти у галузі податків і портових зборів нерідко містять нечіткі формулювання й пробіли регулювання. Крім того, різні органи державної влади та ïx представники найчастіше дають суперечливі тлумачення тих або інших податкових норм, що створює певні протиріччя й неясність. Податкові ризики, пов'язані 3 діяльністю стивідорного підприємства, характерні для більшої частини суб'єктів підприємницької діяльності, що здійснюють свою діяльність на території України.

Стивідорне підприємство $\epsilon$ об'єктом регулювання численних екологічних норм і вимог. Введення нових або зміна існуючих нормативних актів можуть негативно вплинути на операційну діяльність підприємства. Не виключена можливість жорсткості природоохоронного регулювання, а також виникнення судових претензій 3 боку держави й третіх осіб, результатом яких можуть стати додаткові витрати на приведення операційної діяльності у відповідність із новими вимогами, усунення порушень і відшкодування екологічного або майнового збитку.

Правові ризики також включають кримінальні ризики (розкрадання, розкриття контейнерів), ризики пов'язані iз загальним правовим регулюванням в портовій сфері.

Останнім часом розвиваються різні концепції часткової приватизації інфраструктури морських портів, використання договорів концесії, різних договорів оренди. Існують різні думки щодо вирішення питання про приватизацію в сфері портової діяльності, адже приватизація пов'язана зі значними ризиками. Вона може призвести до появи навіть в межах одного порту структур, які будуть стримувати конкуренцію на ринку. Тому, перш ніж почати приватизацію в сфері портової діяльності, необхідно визначитися 3 механізмами забезпечення добросовісної конкуренції на ринку портових послуг, гарантування вантажовласникам обробки вантажів на задекларованих портами умовах. Зараз в Україні ці механізми не досить детально опрацьовані, як в економічному, так і в правовому аспекті.

Організаційно-управлінські ризики включають ризик, пов'язаний 3 плануванням інвестицій, ризик, пов'язаний 3 експлуатаційною діяльністю, кадрові ризики. Ризик, пов'язаний з плануванням інвестицій, включає маркетинговий i інформаційний ризик. Говорячи про кадрові ризики на підприємствах портової діяльності, правомірно виділити ту частину ризиків, яка виникає внаслідок прояву якостей і поведінки персоналу. Більше того, аналіз природи внутрішніх ризиків дозволяє зробити висновок про те, що джерелом виникнення більшості 3 них $\epsilon$ саме людський фактор. Ризики форсмажор пов'язані 3 дією обставин 
нездоланної сили (стихійні лиха, військові дії, страйки портових робочих, революція і т.п.).

Для оцінки рівня ризиків інвестиційного проекту будівництва вантажного причалу в порту можливо використовувати метод аналізу чутливості показників доходності проекту і метод сценаріїв. Цей аналіз проводиться у кілька етапів: встановлення формального зв'язку між результативним та формуючими його вихідними показниками; визначення найбільш ймовірних значень для вихідних показників та можливий розмах їх змін; дослідження впливу зміни значень вихідних показників на кінцевий результат. В якості параметрів проекту, на які впливають найбільш важливі фактори ризику, можуть бути обрані, наприклад, експлуатаційні доходи від стивідорної та інших видів діяльності, експлуатаційні витрати i величина капітальних інвестицій. В якості показників кількісної оцінки ризиків проекту пропонується використовувати середне очікуване значення NPV, стандартне відхилення, коефіцієнт варіації, ризик неефективності проекту, сумарний ризик по NPV.

Для мінімізації ринкових та галузевих ризиків слід вживати такі заходи, як: залучення додаткових вантажопотоків, використання високопродуктивного встаткування i технологій, збільшення інтенсивності навантажувально-розвантажувальних

робіт, зниження собівартості послуг, застосування конкурентоспроможних тарифів. Для мінімізації інфляційних ризиків у випадку стрімкого зростання інфляції підприємство необхідно приділяти особливу увагу підвищенню оборотності оборотних активів, у першу чергу, за рахунок скорочення запасів, а також переглянути існуючі договірні відносини зі споживачами 3 метою скорочення дебіторської заборгованості. Для мінімізації ризику ліквідності підприємству необхідно здійснювати ретельне управління і контроль ліквідності.

Висновок. Інвестиційні проекти розвитку портової інфраструктури, які пов'язані 3 капітальним будівництвом у морських портах, характеризуються високим рівнем складності та капіталомісткості. Важливою частиною техніко-економічного обгрунтування таких проектів $\epsilon$ обгрунтування економічної ефективності інвестицій, яке має враховувати галузеву специфіку портової діяльності. У зв'язку з цим методичні підходи до економічного обгрунтування інвестицій у будівництво причалів мають включати низку етапів, пов'язаних 3 визначенням обсягів транспортної роботи, обгрунтуванням доцільності збільшення пропускної спроможності порту або терміналу 3 урахуванням структури вантажообігу i оборотності причалів, визначенням проектних показників 3 урахуванням потреби обробки суден певного розміру, виявленням вузьких місць роботи порту та ін.

Запропонована класифікація ризиків, пов'язаних 3 інвестиційними проектами у портах і стивідорною діяльністю, передбачає виділення галузевих, країнових, фінансових, правових, організаційно-управлінських ризиків i ризиків форс-мажор. У ході економічного обгрунтування для кожного конкретного інвестиційного проекту слід визначати індивідуальний набір факторів за запропонованими групами ризиків. У якості основних параметрів проекту будівництва причалу, які впливають на економічний ефект від його реалізації, пропонується прийняти експлуатаційні доходи від стивідорної та інших видів діяльності, експлуатаційні витрати та капітальні витрати на будівництво i придбання перевантажувального обладнання. Результати кількісної оцінки основних видів ризику проекту мають обов'язково доповнювати оцінку доходності інвестицій, і є підставою для 
прийняття рішення щодо доцільності реалізації проекту і розробки заходів щодо мінімізації рівня ризику. Заходи щодо мінімізації рівня ризику мають бути розроблені для кожної групи ризиків проекту.

\section{ПЕРЕЛІК ВИКОРИСТАНИХ ДЖЕРЕЛ}

1. Розпорядження КМУ від 30 травня 2018 р. № 430-р «Про схвалення Національної транспортної стратегії України на період до 2030 року». Урядовий портал [Електронний ресурс]. Режим доступу: https://www.kmu.gov.ua /ua/npas/pro-shvalennya-nacionalnoyitransportnoyi-strategiyi-ukrayini-na-perioddo-2030-roku - Назва з екрана.

2. Musso E.L. Port management performance and contextual variables: Which relationship? Methodological and empirical issues / E.L. Musso, A.S. Bergantino, F. Porcelli // Research in Transportation Business \& Management. - 2013. - № 8. - P. 39-49.

3. Кібік О.М. Передумови розвитку господарської діяльності портових підприємств / О.М. Кібік // Розвиток методів управління та господарювання на транспорті. - Одеса: ОНМУ, 2008. - № 28. - C. 28-36.

4. Примачев Н.Т., Эффективность развития морской транспортной индустрии: монографія / Н.Т. Примачев, Н.Н. Примачева. Одесса: ОНМА, 2011. $374 \mathrm{c}$.

5. Краев В.И. Экономическая оценка инвестиций на водном транспорте: навчальний посібник / В.И. Краев, Т.А. Пантина. - Санкт-Петербург: СПбГПУ, 2003. -299 c.

6. Кулаев Ю.Ф. Методы оценки инвестиционных проектов на транспорте: монография / Ю.Ф. Кулаев. - К.: Транспорт України, 2001. - 182 с.

7. Бланк И.А. Инвестиционный менеджмент: навчальний посібник / И.А. Бланк. - К.: Эльга-Н, Ника-Центр, 2001. $448 \mathrm{c}$.
8. Бланк И.А. Управление капиталом / И.А. Бланк. - К.: Эльга, НикаЦентр, 2004. - 576 с.

9. Боди Э. Принципы инвестиций / Э. Боди, А. Кейн, А. Маркус. - М.: Вильямс, 2008. - 982 с.

10. Бочаров В.В. Инвестиционный менеджмент / В.В. Бочаров. - СПб.: Питер, 2000. - 160 с.

11. Гранатуров

B.M.

Экономический риск. Сущность, методы измерения, пути снижения: монографія / В.М. Гранатуров. - М.: ДиС, 2002. -112 с.

12. Гранатуров В.М. Управление предпринимательскими рисками: вопросы теории и практики: монографія / B.M. Гранатуров, И.В. Литовченко. - Одесса: Эвен, 2005. - 204 с.

13. Донець Л.I. Економічні ризики та методи їх вимірювання / Л.І. Донець. К.: Центр навчальної літератури, 2006. $312 \mathrm{c}$.

\section{REFERENCES}

1. Pro skhvalennja Nacionaljnoji transportnoji strateghiji Ukrajiny na period do 2030 roku (2018) [About approval of National transport strategy of Ukraine until 2030]. Decree of the Cabinet of Ministers of Ukraine dated May 30, 2018, No. 430-r. Governmental Portal (electronic resours). Available at: https://www.kmu.gov.ua/ua npas/pro-shvalennya-nacionalnoyitransportnoyi-strategiyi-ukrayini-na-perioddo-2030-roku (accessed 12.10.2019).

2. Musso E.L., Bergantino A.S., Porcelli F. (2013) Port management performance and contextual variables: Which relationship? Methodological and empirical issues. Research in Transportation Business \& Management, no. 8, pp. 39-49.

3. Kibik O.M. (2008) Peredumovy rozvytku ghospodarsjkoji dijaljnosti portovykh pidpryjemstv [Conditions of development of economical activity of port 
enterprises]. Development of management and entrepreneur methods on transport, no. 28, pp. 28-36.

4. Primachev N.T., Primacheva N.N. (2011) Effektivnost' razvitiya morskoy transportnoy industrii [Efficiency of development of maritime transport industry]. Odessa: ONMA (in Russian).

5. Kraev V.I., Pantina T.A. (2003) Ekonomicheskaya otsenka investitsiy na vodnom transporte [Economic evaluation of investments in water transport industry]. Sankt-Petersburg: SPbGPU (in Russian).

6. Kulaev Yu.F. (2001) Metody otsenki investitsionnykh proektov na transporte [Methods of evaluation of investment projects in transport industry]. Kyiv: Transport of Ukraïne (in Russian).

7. Blank I.A. (2001) Investitsionnyy menedzhment [Investment management]. Kyiv: El'ga-N, Nika-Tsentr (in Russian).

8. Blank I.A. (2004) Upravlenie kapitalom [Capital management]. Kiev: El'ga-N, Nika-Tsentr (in Russian).
9. Bodi E., Keyn A., Markus A. (2008) Printsipy investitsiy [Principles of investments]. Moscow: Vil'yams (in Russian).

10. Bocharov V.V. (2000) Investitsionnyy menedzhment [Investment management]. Sankt-Petersburg: Piter (in Russian).

11. Granaturov V.M. (2002) Ekonomicheskiy risk. Sushchnost', metody izmereniya, puti snizheniya [Economic risk. Nature, methods of measuring, ways of minimization]. Moscow: DiS (in Russian).

12. Granaturov V.M., Litovchenko I.V. (2005) Upravlenie predprinimatel'skimi riskami: voprosy teorii $i$ praktiki [Entrepreneurial risks management: questions of theory and practice]. Odessa: Even (in Russian).

13. Donecj L.I. (2006) Ekonomichni ryzyky ta metody jikh vymirjuvannja [Economic risks and methods of its measuring]. Kyiv: Centr navchaljnoji literatury (in Ukraine).

УДК 330.322:656.2

\title{
РОЗРОБЛЕННЯ МОДЕЛІ УПРАВЛІННЯ ІНВЕСТИЦІЙНИМ ЗАБЕЗПЕЧЕННЯМ ПРОЄКТІВ РОЗВИТКУ ІНФРАСТРУКТУРИ ЗАЛІЗНИЧНОГО ТРАНСПОРТУ В УМОВАХ ТРАНСКОРДОННОЇ СПІВПРАЦІ
}

\author{
Корінь М.В., к.е.н., доцент, \\ Абдуллаєв А.І, махістр, \\ Польгуй Д.Г., махістр (УкрДУЗТ)
}

В статті вивчено існуючі підходи до систематизаиії та класифікації ризиків інфраструктурних проєктів. Виділено чотири групи (глобальні, транскордонні, начіональні, галузеві) потенційних ризиків проєктів розвитку інфраструктури залізничного транспорту, щзо реалізуються в рамках транскордонних регіонів. Розроблено модель управління інвестиційним забезпеченням інфраструктурних проєктів розвитку залізничного транспорту, яка трунтується на оцінюванні співвідношення

(C) Корінь М.В.,

Абдуллаєв А.І.,

Вісник економіки транспорту і промисловості № 67, 2019

Польгуй Д.Г. 